\title{
An Epidemiological Model for Externally Sourced Vector-Borne Viruses Applied to Bean yellow mosaic virus in Lupin Crops in a Mediterranean-Type Environment
}

\author{
T. Maling, A. J. Diggle, D. J. Thackray, K. H. M. Siddique, and R. A. C. Jones
}

First, second, third, fourth, and fifth authors: Centre for Legumes in Mediterranean Agriculture, M080, The University of Western Australia, Crawley, WA 6009, Australia; second and fifth authors: Agricultural Research Western Australia, Locked Bag No. 4, Bentley Delivery

Centre, Perth, WA 6983, Australia; fourth author: Institute of Agriculture, The University of Western Australia M082, Crawley, WA 6009,

Australia; and fifth author: School of Plant Biology, The University of Western Australia, Crawley, WA 6009, Australia.

Accepted for publication 30 July 2008.

\begin{abstract}
Maling, T., Diggle, A. J., Thackray, D. J., Siddique, K. H. M., and Jones, R. A. C. 2008. An epidemiological model for externally sourced vectorborne viruses applied to Bean yellow mosaic virus in lupin crops in a Mediterranean-type environment. Phytopathology 98:1280-1290.

A hybrid mechanistic/statistical model was developed to predict vector activity and epidemics of vector-borne viruses spreading from external virus sources to an adjacent crop. The pathosystem tested was Bean yellow mosaic virus (BYMV) spreading from annually self-regenerating, legume-based pastures to adjacent crops of narrow-leafed lupin (Lupinus angustifolius) in the winter-spring growing season in a region with a

drive aphid population increase, migration of aphids from pasture to lupin crops, and the spread of BYMV. The model predicted time of arrival of aphid vectors and resulting BYMV spread successfully for seven of eight datasets from 2 years of field observations at four sites representing different rainfall and geographic zones of the southwestern Australian grainbelt. Sensitivity analysis was performed to determine the relative importance of the main parameters that describe the pathosystem. The hybrid mechanistic/statistical approach used created a flexible analytical tool for vector-mediated plant pathosystems that made useful predictions even when field data were not available for some components of the system.
\end{abstract} Mediterranean-type environment where the virus persists over summer within dormant seed of annual clovers. The model uses a combination of daily rainfall and mean temperature during late summer and early fall to
Additional keywords: forecasting, integrated disease management, risk, simulation.
Many agriculturally important virus-crop pathosystems involve nonpersistently transmitted aphidborne viruses where the virus source is external to the crop that is damaged (19). Bean yellow mosaic virus (BYMV; family Potyviridae; genus Potyvirus) infection of the cool-season grain legume narrow-leafed lupin (Lupinus angustifolius) provides an example of this. BYMV causes a damaging disease of narrow-leafed lupin wherever it is grown, including parts of Europe, North America, Russia, South Africa, and Australia (15). For example, BYMV epidemics pose a major constraint to narrow-leafed lupin production in the grainbelt of southwestern Australia, where up to 1 million ha/year of the crop is grown annually in rotation with cereals $(12,23)$. This region has a Mediterranean-type environment and BYMV spread to crops occurs in the winter-spring growing season (10-12).

Two strain groups of the virus infect narrow-leafed lupin in this region, a common one that causes necrosis and plant death (necrotic group) and another which occurs less frequently that causes mottle, leaf deformation, and plant stunting without necrosis (nonnecrotic group) $(2,3,31)$. These two BYMV strain groups are not distinguished when other host species, such as clover or other lupin species, become infected because the necrotic phenotype is controlled by systemic hypersensitivity gene $\mathrm{Nbm}-1$ which is only present in narrow-leafed lupin $(3,16)$. Only the common necrotic type is considered here. In narrow-leafed lupin, its spread is largely monocyclic because infected plants die rapidly, such

Corresponding author: R. A. C. Jones; E-mail address: rjones@agric.wa.gov.au

doi:10.1094/PHYTO-98-12-1280

(C) 2008 The American Phytopathological Society that they are only available very briefly as an internal infection source $(4,10-13)$. Necrotic BYMV causes yield losses of $>60 \%$ in years when aphids arrive early in the life of the crop and initiate an epidemic that reaches most plants $(10,11,14)$. Annually selfregenerating pastures dominated by subterranean clover (Trifolium subterraneum) act as the principal reservoir for spread of BYMV to lupin crops in the grainbelt, with up to $50 \%$ of clover pastures found infected in a survey $(12,20)$. BYMV is seedborne in annual clover, and survives the dry summer period in dormant clover seed in the seed bank (12,21). However, unlike the BYMV strains found in Europe and North America, it is not seedborne in lupin species in the region $(12,14,15)$; therefore, except when clover weeds occur within the crop, there is no initial internal source of infection. Thus, initial crop infection is entirely dependent upon immigration of infective aphids from external sources.

Aphid vectors spread BYMV from pastures to the edges of adjacent lupin crops where high incidences develop, especially at the windward edge. Subsequently, aphids move the virus deeper into the crop (10-13). Its vectors in the grainbelt include the three main lupin-colonizing species: the cowpea aphid (Aphis craccivora), blue-green aphid (Acyrthosiphon kondoi), and greenpeach aphid (Myzus persicae), and the principal noncolonizing species in the region: the turnip aphid (Lipaphis erysimi), corn aphid (Rhopalosiphum maidis), and oat aphid (R. padi). Because the noncolonizing species do not settle permanently on lupin plants, they have greater potential to spread the virus as they fly through the crop, making brief shallow probes on a number of plants while searching for their preferred host plants. However, the lupin-colonizing species, although less mobile in the crop, are generally more efficient BYMV vectors $(1,12,28)$. The Mediter- 
ranean-type environment of the grainbelt creates a hostile environment for survival of aphid vectors over summer because, in Australia, aphids are entirely parthenogenetic with no egg stage to withstand harsh conditions. During the dry summer months, a few aphids persist on herbaceous host plants surviving in roadside ditches, irrigated gardens, the edges of creeks, and other damp, isolated locations $(12,28)$. The timing and magnitude of rainfall events supporting plant growth in March and April (early fall) in a district is directly related to the date of first arrival of aphids in lupin crops $(12,28)$. When there is little or no rain at this time, very few plants are available to support aphids before crops are sown; therefore, they take longer to build up and arrive in crops much later $(12,28)$. The principal factors driving the epidemics and resulting yield losses are (i) the magnitude of the external primary BYMV source (infected clover pasture) and its proximity to lupin crops; (ii) the time of first arrival of aphid vectors in lupin crops and their abundance and activity; (iii) which aphid species are involved and whether they colonize lupins or not; (iv) climatic factors, including rainfall, temperature, and evaporation; and (v) cultural factors that determine plant density, time of canopy closure, and extent of ground cover (10-13).

In the BYMV narrow-leafed lupin pathosystem, epidemics can be managed using an integrated disease management (IDM) approach involving cultural and phytosanitary control measures (12). However, epidemics are sporadic $(2,12)$ and the management methods are costly; therefore, an assessment of risk is desirable. At the time when management decisions need to be made (sowing time), some relevant information is available, such as weather data. Other relevant information, such as vector populations, BYMV incidence in source plants, and the spatial relationship between the source of the virus and the crop, typically are not known or are variable between cropping fields. Models to forecast epidemics of BYMV in lupins need to do so in time to influence crop management decisions made at sowing time. To simulate aphid-borne virus epidemics, the required features of a model depend on whether the source of the virus is internal or external, whether transmission is persistent or nonpersistent, and whether spread is monocyclic or polycyclic. Past models have been developed for internally sourced, nonpersistently aphidborne, polycyclic virus-crop pathosystems, such as Soybean mosaic virus (family Potyviridae; genus Potyvirus) in soybean $(7,25)$ and Cucumber mosaic virus (family Bromoviridae; genus Cucumovirus) in narrow-leafed lupin (28), and for externally sourced, persistently aphid-borne, polycyclic pathosystems such as 'virus yellows' disease in sugar beet (32) and Barley yellow dwarf virus (family Luteoviridae; genus Luteovirus) in cereals (18). However, to our knowledge, there are no models for the scenario where an externally sourced, nonpersistently transmitted aphid-borne virus has a monocyclic pattern of spread within a crop, as with BYMV in narrow-leafed lupin.

When modeling insect-vectored virus-crop pathosystems, mechanistic and statistical methodologies may be used. Mechanistic models use logical assumptions and expert knowledge to describe the underlying processes of a system. For example, Holt et al. (6) created an original mechanistic model for Tomato leaf curl virus (family Geminivirideae; genus Begomovirus) in tomato, estimating parameters using data from several experimental studies. Such models rely on a well-quantified understanding of all processes of key importance for their accuracy, and a trade-off exists between complexity and accuracy of prediction due to accumulation of error in estimating the parameters (22). Statistical models often use regression analyses of observations to provide a description of the relationships between the variables in the system. For example, Werker et al. (32) designed a model of 'virus yellows' incidence in sugar beet by both adapting an existing statistical infection model with expert knowledge of the pathosystem and then fitting model parameters using statistical methodology. As the basis for their predictions, they used the relationships between measures of experimental conditions and experimental results. The derivation and reliability of such statistical models is clear, but the underlying relationships have no biological basis because they don't use knowledge of pathosystem mechanics. Models often use a combination of approaches.

The aims of this study were to (i) develop a hybrid mechanistic/ statistical model to predict vector activity and epidemics of a vector-borne viruses spreading from external virus sources to an adjacent crop; (ii) apply this model to the BYMV lupin pathosystem to create a forecasting model for use in assisting virus management decisions in narrow-leafed lupin crops; (iii) calibrate the model against 2 years of field data from four sites representing different rainfall and geographic zones; and (iv) perform a sensitivity analysis of the key parameters, including those likely to be influenced by management practices.

\section{MATERIALS AND METHODS}

Assumptions and approach. The model simulates a single lupin crop adjacent to a BYMV-infected annually self-regenerating pasture dominated by clover which constitutes the only source of the virus because no clover weeds are present within the crop. Key assumptions made in developing the BYMV prediction model for this scenario were (i) aphid species moving from the pasture are grouped into lupin-colonizing and lupin-noncolonizing species, each with their own transmission efficiencies and flight behaviors, alatae belonging to both groups being responsible for all the virus spread; (ii) time of first arrival of aphids in the lupin crop depends on the amount and duration of pasture growth (biomass) and the aphid population in the pasture, which in turn depends on rainfall and temperature during the late summer-early fall period before the lupin crop is sown; (iii) the probability that an aphid migrating from the pasture into the crop is infectious is dependent on the BYMV incidence in the adjacent pasture; (iv) aphids fly from the clover pasture first to the perimeter of the lupin crop, and from there to the interior of the lupin crop; (v) the common (necrotic) strain group of BYMV is the only one present; (vi) each lupin plant is in one of four states-healthy, latently infected, infective, or dead-and, because the duration of its infective stage is very brief, spread is largely monocyclic; and (vii) incidence of seedborne BYMV in the annual clover seed bank and mortality of aphids due to predators and entomopathogenic diseases is higher in areas that historically have more suitable conditions for increase in aphid population in fall and an extended period of pasture growth in spring.

Our methodology uses both statistical and mechanistic techniques in model creation and parameter estimation. This allows us to use existing experimental data to directly calibrate individual processes in the model where available. Where data is not available for parameters relating to a particular process, such as the spatial variability of BYMV incidence in clover pastures, parameters can be calibrated less directly using data that ultimately depend on that process, such as disease incidence in the crop. In the model, pasture biomass and pasture aphid populations are represented as indices ( 0 to 1$)$ rather than as explicit values $\left(\mathrm{g} / \mathrm{m}^{2}\right.$ or aphids $/ \mathrm{m}^{2}$ ). These indices are converted to explicit values when simulating aphid movement and spread of BYMV into the lupin crop. The scaling parameters necessary to convert these indices to explicit values were determined via calibration against empirical data, including satellite imagery, aphid population counts, and virus incidence measurements made at different times in the crop.

Model description, parameterization, and data sources. The parameters and variables used throughout the model, including a description of each value and whether it was sourced from the literature (experimental data or other models), fitted during calibration, or, in one case, from expert opinion, are shown in Table 1. The simulation calculations involve four major processes: (i) 
buildup of biomass in the adjacent clover pasture; (ii) buildup and activity of aphid populations in the pasture; (iii) migration of infectious aphids to the perimeter of the lupin crop, and from the perimeter to the interior of the lupin crop; and (iv) multiplication, movement, and spread of BYMV by aphids within the crop.

For all localities used in model development and calibration, 'SILO Patched Point' national daily maximum and minimum temperature, rainfall, and pan evaporation data sets from the
Queensland Department of Natural Resources and Mines project to provide web access to a range of agrometeorological data were employed (8). The model and its interface to the meteorological database were written in Java programming language. A flow diagram showing the overall model processes and structure is provided in Figure 1. Temperature, rainfall, and pan evaporation data drive calculations of evapotranspiration (Table 2, equation 1), drainage (Table 2, equation 2), and, ultimately, soil moisture

TABLE 1. Descriptions of parameters and variables used in the model, their sources, and the equations utilizing them ${ }^{\mathrm{a}}$

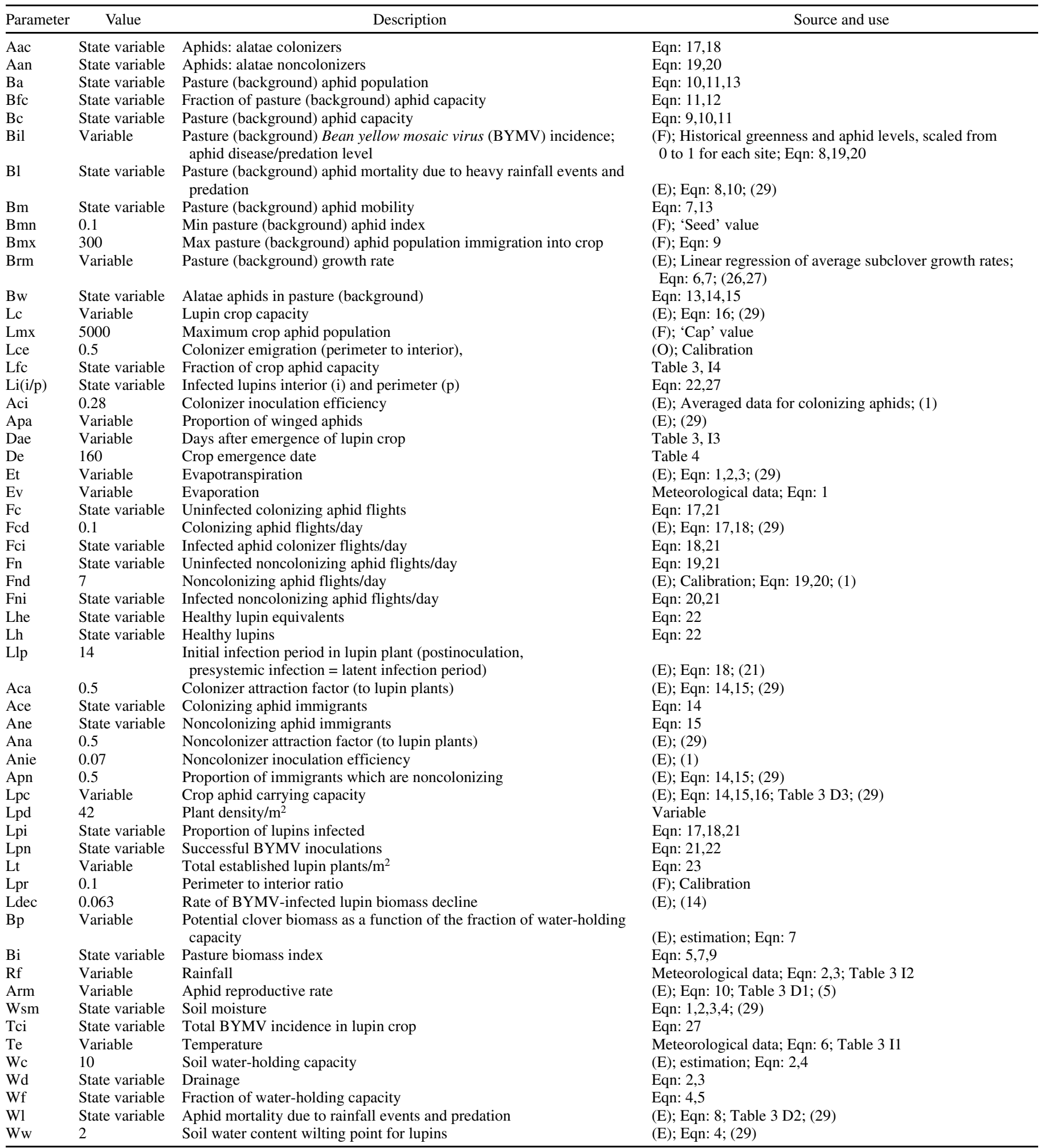

${ }^{\mathrm{a}}$ In the variables, A refers to aphid, B to background or pasture, $\mathrm{F}$ to vector flight, $\mathrm{L}$ to lupin crop, and $\mathrm{W}$ to water. Parameters were sourced from the literature $($ E), from expert opinion $(\mathrm{O})$, or fitted via model output $(\mathrm{F})$. 
(Table 2, equation 3). These equations were from Thackray et al. (28). The fraction of water-holding capacity (Table 2, equation 4) is used to determine the maximum pasture biomass capacity for a given day (Table 2, equation 5). The rate at which pasture biomass approaches capacity is governed by temperature (Table 2, equations 6 and 7). Equation 6 is based on multiple linear regression of average growth rates for subterranean clover $(26,27)$. The pasture biomass for any given day is then calculated as an index (Table 2, equation 7). This pasture biomass value represents the growth of annual clovers and other plants within mixed-species annual pastures, such as grasses and broadleaf weeds, which can support populations of different aphid species. Biomass patterns were calibrated against monthly maps of normalized difference vegetation index imagery (NDVI) from the United States National Oceanic and Atmospheric Administration (NOAA) satellite from 1997 to 2005.

The aphid population in the pasture is limited by available pasture biomass (Table 2, equation 9). The rate at which aphids multiply to reach this limit is governed by temperature (Table 3, I1/D1) as described by Dixon (5), with a maximum reproductive rate of six young per day at the optimal temperature of $25^{\circ} \mathrm{C}$. Heavy rainfall events increasing aphid mortality (Table 3, I2/D2), with a maximum of $55 \%$ of the population killed during rainfall events of greater than $30 \mathrm{~mm}$, as used by Thackray et al. (28). We

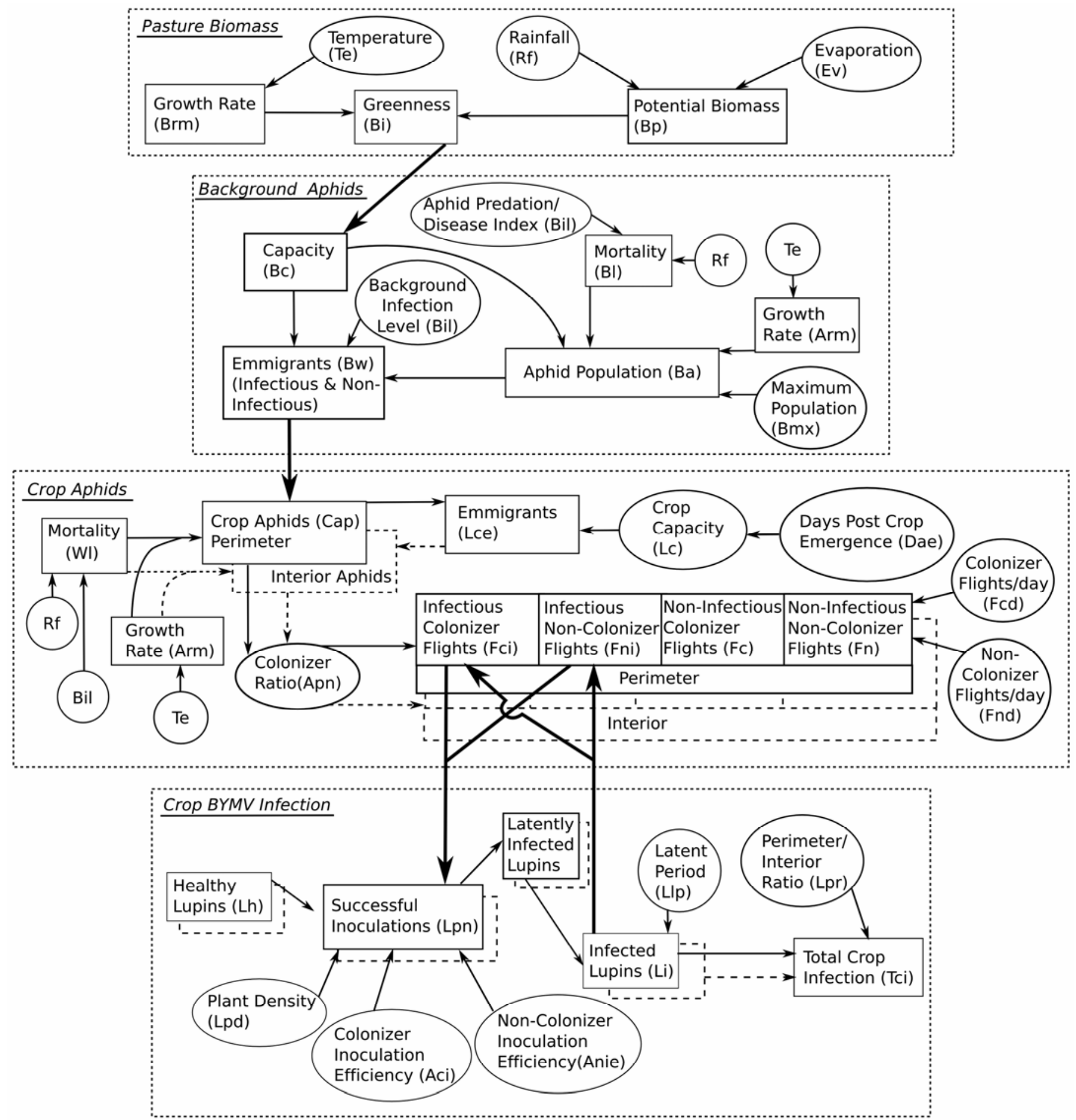

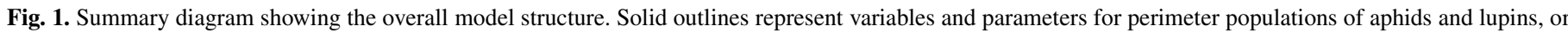
those that are equal for both perimeter and interior populations; dashed outlines represent variables from the interior populations of aphids and lupins. 
included a representation of the effects of aphid predation and entomopathogenic disease, called the BYMV infection and predation index (Table 1, Bil; Table 2, equation 8). This parameter was also used to estimate local pasture BYMV incidence, and was set based on the number of days in each year that the modeled pasture biomass and pasture aphid population indices (Table 1, Bi and $\mathrm{Ba}$ ) exceeded thresholds of 0.5 for the calibration sites between 1957 and 2006. This method assumes that locations with a history of extended periods of environmental conditions conducive to increase in pasture biomass and large aphid populations will have built up a larger proportion of BYMV infection in the clover seed bank and will have larger populations of aphid predators and entomopathogenic diseases. The threshold value was chosen to most closely reproduce the relative aphid numbers and virus incidence between calibration sites. The interaction between aphid reproduction, pasture capacity, and aphid mortality produces the calculation of a pasture aphid population index for any given day (Table 2, equation 10 ).

Calculation of migration of aphids from the pasture into the adjacent lupin crop has a mechanistic basis, with the transformation of the pasture aphid population index into real population numbers calibrated via comparison with observed crop aphid populations (28). Given that the scenario being modeled is where the lupin crop is directly adjacent to a clover pasture, it was estimated that $50 \%$ of the aphids would move from the pasture to the crop perimeter and the other $50 \%$ would move away from the crop (Lce). Parameter Lce was based on the expert opinion of the authors after many years of study of this pathosystem, starting in approximately 1990 (10-13). Migration is dependent on population density, because crowding causes an increase in production of alatae (5). Aphid population as a proportion of capacity is calculated (Table 2, equation 11). This value is used to determine the proportion of aphids that are alatae (Table 2, equations 12 and 13). Thus, alterations in the pasture aphid population are used to predict the development of winged aphids and the migration of colonizing (Table 2, equation 14) and noncolonizing (Table 2, equation 15) alatae into the lupin crop. An inverse relationship exists between the distance from the crop perimeter and the number of BYMV-infected plants (13). In consequence, aphids and lupin plants within the crop are split into perimeter and interior populations, with aphids moving from the pasture to the perimeter population initially and then from the perimeter to the interior. The probability that an aphid migrating from the pasture into the crop is infectious is dependent on the BYMV incidence in the adjacent pasture. In turn, the probability that an aphid moving from the perimeter to the interior is infectious is dependent on the proportion of the lupin biomass in the perimeter that is infected. Migration of colonizing aphids into the lupin crop and the increase in their population after arrival are mediated by the same functions as those used for aphid population growth in pasture; however, the population is limited by available crop biomass rather than pasture biomass, with the maximum population capacity occurring 80 days after the emergence of the lupin crop (Table 3, I3/D3; Table 2, equation 16). The alatae proportion of the crop aphid population depends on the fraction of the maximum aphid-carrying capacity that is present in the lupin crop, with a maximum of $78 \%$ of offspring being alatae when the population reaches $90 \%$ of this capacity (Table 3, I4/D4). Noncolonizing aphid species within the lupin crop undertake more flights per day than colonizing aphids as they search for a plant belonging to their preferred host species (Table 1, Fcd, Fnd) $(1,28)$. The numbers of noninfectious colonizing (Table 2 , equa-

TABLE 2. List of important equations used in the model

\begin{tabular}{|c|c|}
\hline Equation number & Equation \\
\hline 1 & $\mathrm{Et}=\mathrm{Wsm} \times 0.03 \times(\mathrm{Ev} / 6)$ \\
\hline 2 & $\mathrm{Wd}=\mathrm{Wsm}+\mathrm{Rf}-\mathrm{Et}-\mathrm{Wc}$ when $>0$ else $\mathrm{Wd}=0$ \\
\hline 3 & $W \operatorname{sm}(t)=W \operatorname{sm}(t-1)+R f-(E t+W d)$ \\
\hline 5 & $\mathrm{Bp}=1 /\left(1.0+\mathrm{e}^{(7-(10 \times \mathrm{WF}))}\right)$ \\
\hline 6 & $\mathrm{Brm}=(-0.12)+0.026 \times \mathrm{Te}-0.0007 \times \mathrm{Te}^{2}$ \\
\hline 7 & $\operatorname{Bi}(t)=\operatorname{Bi}(t-1)+\operatorname{Brm} \times \operatorname{Bi}(t-1)$ when $B i(t-1)<B p$ else $B i(t)=B p$ \\
\hline 8 & $\mathrm{Bl}=\mathrm{Wl}+((\mathrm{Ba}-\mathrm{Wl}) \times \mathrm{Bil} \times 0.1)$ \\
\hline 11 & $\mathrm{Bfc}=\mathrm{Ba} / \mathrm{Bc}$ \\
\hline 12 & $\mathrm{Bm}=0.34 \times \mathrm{Bfc}-0.33$ \\
\hline 13 & $\mathrm{Bw}=\mathrm{Ba} \times \mathrm{Bm}$ \\
\hline 14 & Ace $=\mathrm{Bw} \times \mathrm{Lpc} \times \mathrm{Aca} \times(1-\mathrm{Apn})$ \\
\hline 15 & $\mathrm{Ane}=\mathrm{Bw} \times \mathrm{Lpc} \times \mathrm{Aca} \times(\mathrm{Apn})$ \\
\hline 16 & $\mathrm{Lc}=\mathrm{Lmx} \times \mathrm{Lpc}$ \\
\hline 17 & $\mathrm{Fc}=\mathrm{Aac} \times \mathrm{Fcd} \times(1-\mathrm{Lpi})$ \\
\hline 23 & $\mathrm{TYl}=(\mathrm{Lpr} \times \mathrm{Ylp})+((-1 \mathrm{Lpr}) \times \mathrm{Yli})$ \\
\hline 24 & $\mathrm{TCi}=((\mathrm{Lpr} \times \mathrm{Icp}+(1-\mathrm{Lpr}) \times \mathrm{Ici}) / \mathrm{Lpd}) \times 100$ \\
\hline
\end{tabular}

TABLE 3. Independent variables (I) and dependent variables (D) used in the model

\begin{tabular}{|c|c|c|c|c|c|c|c|c|c|c|c|}
\hline I, D & Symbol & & & & & & & & & & \\
\hline $\mathrm{I}_{1}$ & $\mathrm{Te}$ & 0 & 5 & 10 & 15 & 20 & 25 & 30 & 35 & $>40$ & $\ldots$ \\
\hline $\mathrm{D}_{1}$ & Arm & 0 & 1.05 & 3 & 4.62 & 5.94 & 6 & 5.4 & 4.8 & 0 & $\ldots$ \\
\hline $\mathrm{I}_{2}$ & $\mathrm{Rf}$ & 1.5 & 2 & 2.5 & 3 & $>3$ & $\ldots$ & $\ldots$ & $\ldots$ & $\ldots$ & $\ldots$ \\
\hline $\mathrm{I}_{3}$ & Dae & 0 & 20 & 40 & 60 & 80 & 100 & 120 & 140 & $\ldots$ & $\ldots$ \\
\hline $\mathrm{D}_{3}$ & Lpc & 0 & 0.18 & 0.64 & 0.97 & 1 & 0.28 & 0.02 & 0 & 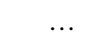 & $\ldots$ \\
\hline $\mathrm{I}_{4}$ & Lfc & 0 & 0.1 & 0.2 & 0.3 & 0.4 & 0.5 & 0.6 & 0.7 & 0.8 & 0.9 \\
\hline $\mathrm{D}_{4}$ & Apa & 0.1 & 0.22 & 0.35 & 0.45 & 0.53 & 0.6 & 0.66 & 0.72 & 0.76 & 0.78 \\
\hline
\end{tabular}


tion 17), infectious colonizing (Table 2, equation 18), noninfectious noncolonizing (Table 2, equation 19), and infectious noncolonizing (Table 2, equation 20) aphid flights per day are used to calculate the number of successful lupin inoculations per day (Table 2, equation 21), given the inoculation efficiencies of the colonizing and noncolonizing aphids. These parameter values are the averaged efficiencies for colonizing and noncolonizing aphid species from Berlandier et al. (1), and describe the probability that an infectious aphid will transmit the virus when probing the lupin plant. From this, the number of infected plants is determined (Table 2, equation 22).

Once a lupin plant is infected with BYMV, it undergoes a latent period before it becomes infected systemically (Table 1, Llp). Using the relationship between time of infection and biomass defined by Jones et al. (14), an infected plant loses relative biomass each day between initial infection and death. As such, there is a very brief window in which it acts as an internal virus source before it dies $(1,10,13,31)$. Infection incidence for perimeter and interior lupin plant populations are then combined to give the final BYMV incidence values (Table 2, equation 23).

Calibration data. Simulation outputs from the model were calibrated using aphid population and BYMV incidence data collected from blocks of lupins located in different rainfall and geographic zones (Fig. 2). These were positioned next to annual clover pastures over 2 years (1998 and 1999) at four sites (28$30)$. These sites were Badgingarra $\left(30^{\circ} 23^{\prime} \mathrm{S}, 115^{\circ} 30^{\prime} \mathrm{E}\right)$ in the high-rainfall zone of the northern grainbelt of Western Australia (594 $\mathrm{mm}$ average rainfall), Avondale $\left(32^{\circ} 07^{\prime} \mathrm{S}, 116^{\circ} 51^{\prime} \mathrm{E}\right)$ in the medium-rainfall zone in the central grainbelt $(421 \mathrm{~mm})$, Merredin $\left(31^{\circ} 30^{\prime} \mathrm{S}, 118^{\circ} 17^{\prime} \mathrm{E}\right)$ in the low-rainfall zone of the central grainbelt $(324 \mathrm{~mm})$, and Mount Barker $\left(34^{\circ} 38^{\prime} \mathrm{S}, 117^{\circ} 32^{\prime} \mathrm{E}\right)$ in the high-rainfall zone in the southern grainbelt $(748 \mathrm{~mm})$ (Fig. 2) (28-30). At each calibration block, colonizing aphid populations were recorded by counting the number of aphids on the top $10 \mathrm{~cm}$ of the uppermost growing tip of a random selection of 50 lupin plants, sampled in a W pattern across each block. This was done every 2 weeks during the growing season at Avondale, Badgingarra, and Mount Barker but, at Merredin, only once in 1998 and twice in 1999. These counts were then converted to aphids $/ \mathrm{m}^{2}$ for comparison to model outputs for 1998 and 1999. The numbers of plants with and without typical necrotic BYMV symptoms were assessed by selecting one plant at random every five paces while walking in a W pattern across the block, until 100 to 200 plants were counted during each assessment. Percent BYMV incidence values were then calculated. Aphid and virus counts ceased in spring after no aphids were found for 3 weeks or more, usually in early to mid-October.

The model was calibrated to best fit the data across all years and sites. We calibrated it for the first years' data set at one site and then across all sites for the first year to obtain the best fit to the data. This process was repeated for the second years' data to obtain the best fit across all eight data sets.

Parameter sensitivity analyses. The effects of a range of values for timing of crop emergence, lupin plant densities, and pasture BYMV infection incidence on model predictions for BYMV incidence in crops were studied to establish their relative importance and confirm that each parameter chosen was appropriate for all sites. These parameters were chosen because they are the factors most likely to be manageable in real-world scenarios, and their sensitivity needed to be confirmed to justify the model's use as a tool for management. Sensitivity analyses were also performed on parameters derived from the literature (referred to in Table 1), including colonizing and noncolonizing aphid inoculation efficiencies (Aci, Anie) and number of flights per day (Fcd, Fnd), plant latent infection period (Llp), and rate of lupin biomass decline due to infection ( $\mathrm{Ldec})$. These analyses utilized meteorological data from the 1998 and 1999 calibration blocks at Badgingarra (see previous section).

\section{RESULTS}

The simulated outputs for two intermediate process values, pasture biomass and pasture aphid population, and for the resulting time of first aphid arrival, increase in population of aphids, and BYMV incidence in the crop at the Badgingarra site in 1998 and 1999 are shown in Figure 3. A drier start to the year led to pasture biomass incidence remaining low for a month longer in 1998 than in 1999 which, in turn, led to a delayed build up of the aphid population in the clover pasture, later time of first arrival of aphids in the crop, and, ultimately, lower BYMV crop incidences. This result illustrates the causal chain that is embodied in the model. The reason why aphid populations in the lupin crop declined earlier than those in the pasture was due to the earlier senescence of the lupin crop, as described by variables Dae and Lpc in Table 3.

In both years at the Avondale site, there was good correspondence between predicted and counted aphid population numbers within the lupin blocks (Figs. 4 and 5). Both the timing of initial arrival of aphids and the aphid population size were predicted accurately for both years at Badgingarra, except that the model slightly overpredicted the aphid population during 1998, with the peak population count being only $75 \%$ of the predicted population. The model predictions also provided a close fit at Mount Barker for 1999 but vastly overestimated the 1998 aphid population at this site, with model populations peaking at the maximum of 3,500 aphids $/ \mathrm{m}^{2}$ compared with the measured value of 15 aphids $/ \mathrm{m}^{2}$. For 1998 , the aphid population curve actually aligned with the crop capacity curve (Table 2, I3/D3), signifying that the model predicted no restraints on the aphid population. At Merredin, the model estimated the initial incursion of aphids well for 1999. However, it predicted that the peak aphid population would occur earlier, with lower numbers of aphids. The aphid population at the Merredin site was counted only once during the 1998 growing season and this measurement agreed with the model's output, but further calibration was not possible because of the limited number of counts available.

BYMV incidence counts at different times and model predictions were compared as disease progress curves for 1998 (Fig. 6) and 1999 (Fig. 7). Predictions of BYMV incidence at Badgingarra and Avondale were in agreement in both years, with the model effectively resolving the differences between sites and years. In 1998 at Badgingarra, BYMV incidence increased rapidly and then suddenly remained constant. This was due to senescence of the lupin crop causing the aphid population to decline, precluding

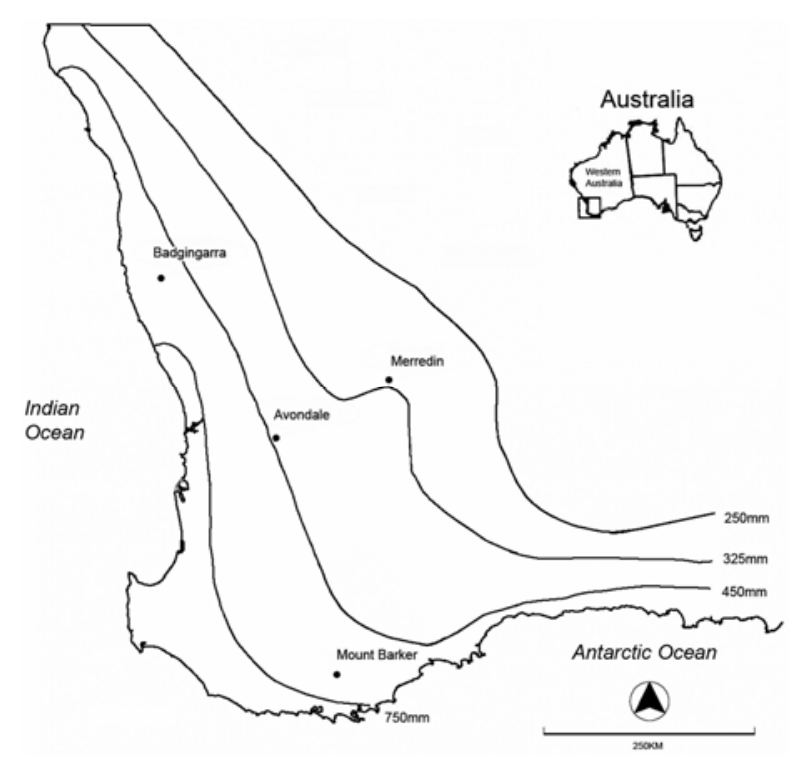

Fig. 2. Map showing rainfall regions of the grainbelt of southwestern Australia and locations of trial sites used to calibrate the model. 
further new BYMV infections. Lupin senescence is described by variables Dae and Lpc in Table 3. In 1999, the model accurately predicted BYMV incidence at Mount Barker but, in 1998, a much higher incidence was predicted at this site than actually occurred, a direct result of the overestimated aphid population. No BYMV infection was observed for either year in lupin plants at the Merredin site. For the 2 years at Merredin when no BYMV was found, the model performed well, predicting only a minimal BYMV incidence.
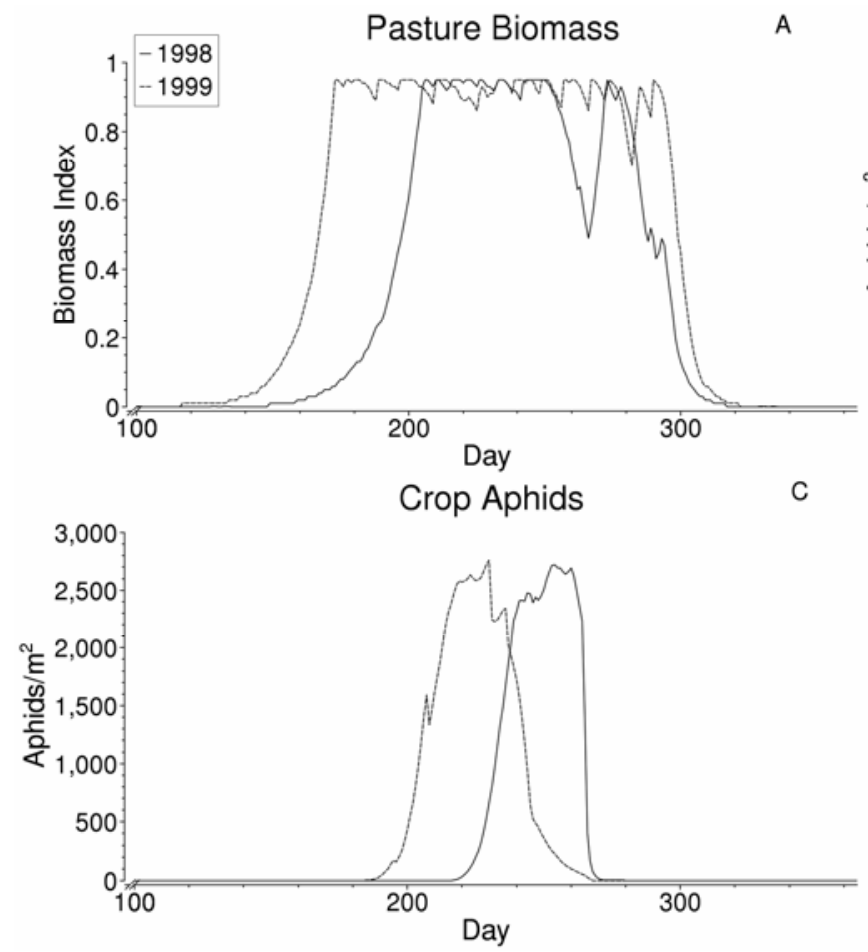

Sensitivity analyses were made to determine the effect of changes in parameter values for timing of crop emergence (Table 1, De), lupin plant densities (Table 1, Lpd), and pasture BYMV incidence (Table 1, Bil) (Table 4) on model predictions for BYMV incidence in crops at Badgingarra in 1998 and 1999. These parameters represent attributes of the pathosystem that can be managed by lupin farmers. The sets of values tested were chosen to encompass a range of realistic values for each parameter. Delaying the time of crop emergence resulted in increasing

Fig. 3. Simulation results for $\mathbf{A}$, pasture biomass levels; B, pasture and $\mathbf{C}$, crop aphid populations (aphids $/ \mathrm{m}^{2}$ ); and $\mathbf{D}$, Bean yellow mosaic virus infection incidence for 1998 and 1999 at Badgingarra.
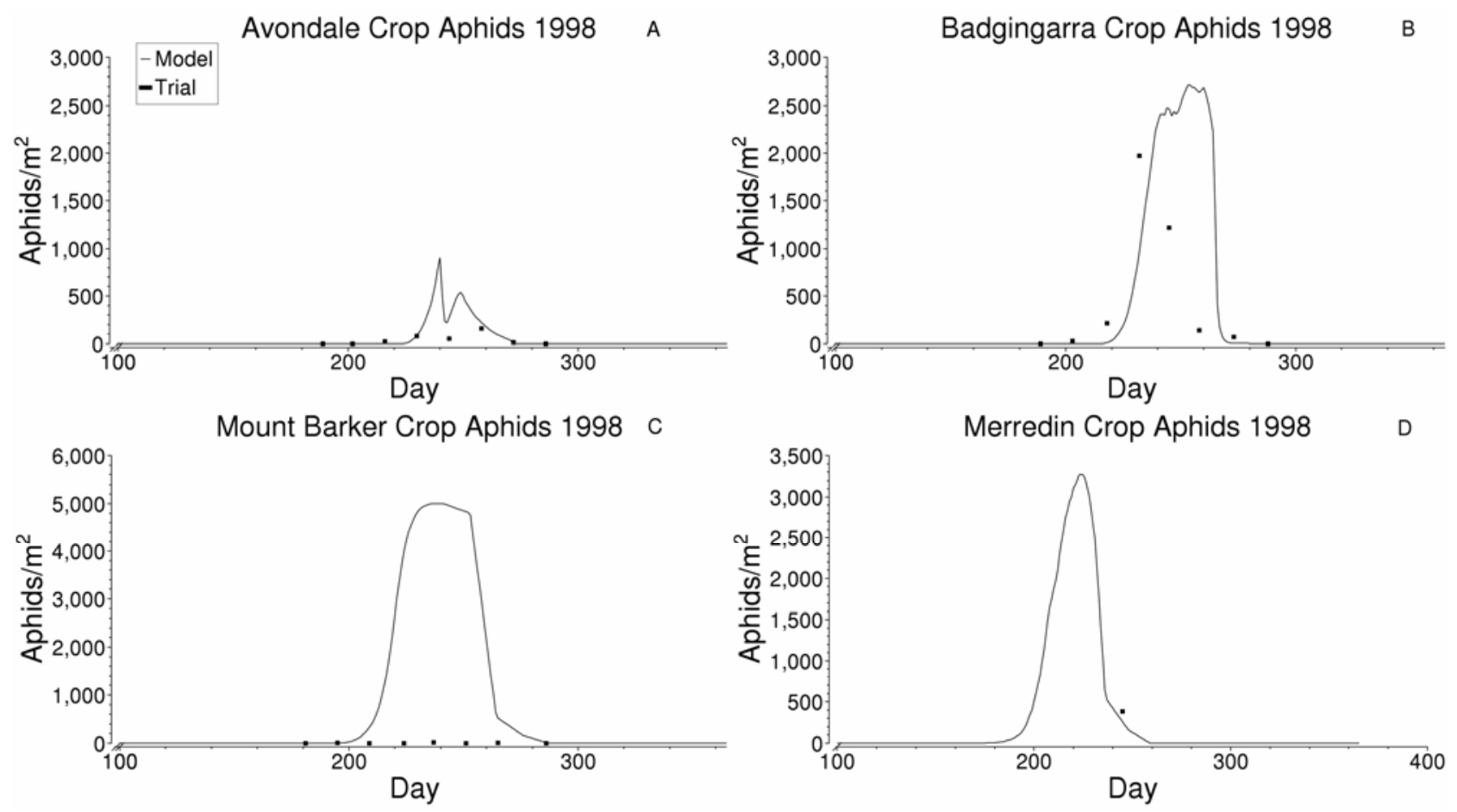

Fig. 4. Observed (trial data) versus predicted (model output) aphid populations (aphids $/ \mathrm{m}^{2}$ ) in lupin during 1998 at A, Avondale; B, Badgingarra; C, Mount Barker; and D, Merredin. 
incidences of BYMV of up to a maximum of $16 \%$ for emergence on day 200 for 1999 and $2 \%$ on day 180 for 1998. Later emergence dates resulted in progressively lower BYMV incidences, showing the relationship between the timing of crop emergence and the date at which aphids first arrive in the crop; the longer both aphids and a lupin crop are present at the same time, the higher the potential final BYMV incidence. For both years, incidence of BYMV in the crop decreased as lupin plant density increased because, as densities increase, each individual infected plant accounts for a relatively smaller percentage of the crop $(10,11)$. Lupin BYMV incidence increased at a decreasing rate as BYMV incidence increased in the pasture. This diminishing returns relationship occurred as the rate of transmission of BYMV incidence to the lupin crop became limited by vector populations rather than the magnitude of the infection source.

Final BYMV incidence in lupin was very responsive to changes in aphid inoculation efficiencies between 0 , inability to transmit the virus, and 1, all feeding events resulting in successful inocu-
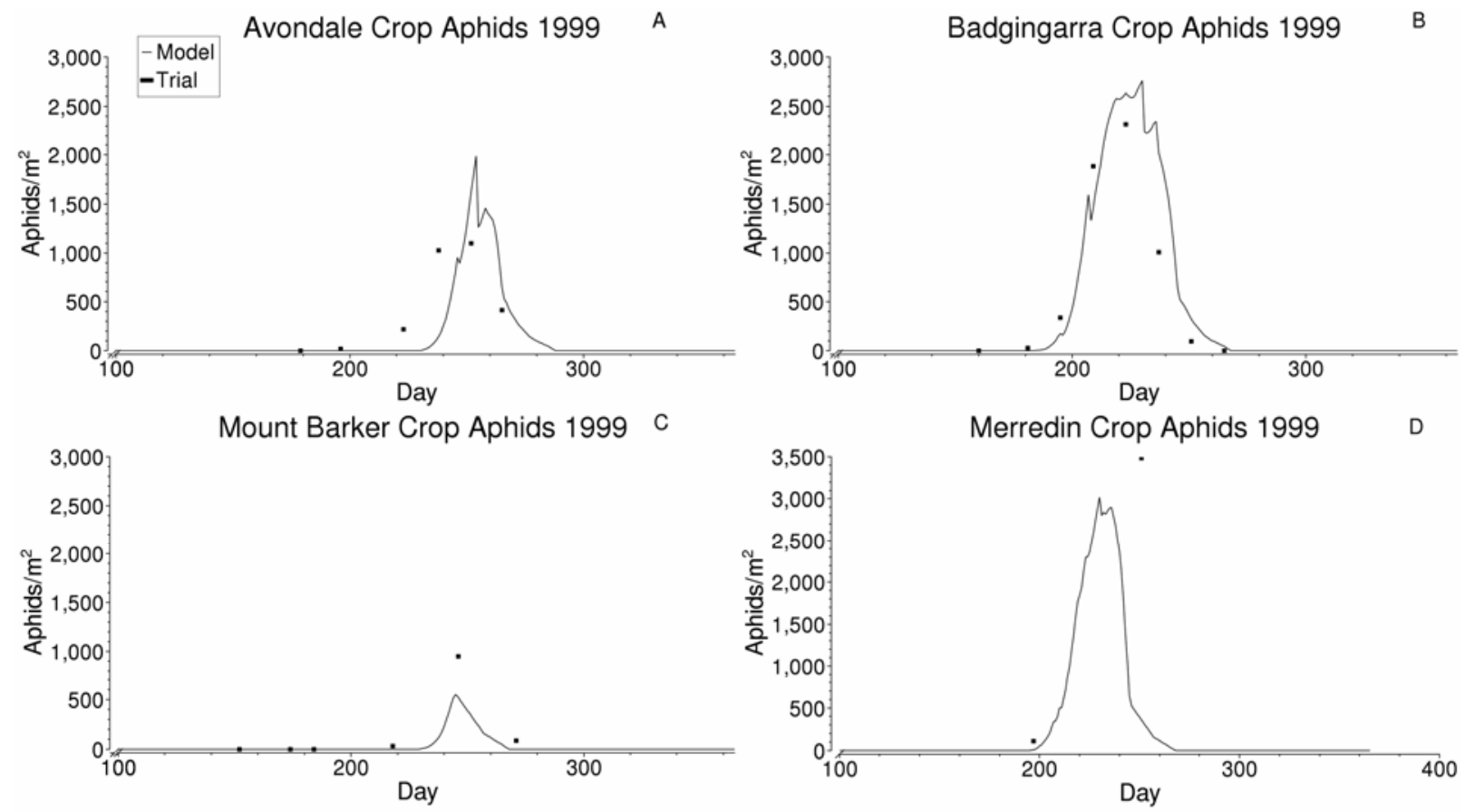

Fig. 5. Observed (trial data) versus predicted (model output) aphid populations (aphids $/ \mathrm{m}^{2}$ ) in lupin during 1999 at A, Avondale; B, Badgingarra; C, Mount Barker; and D, Merredin.
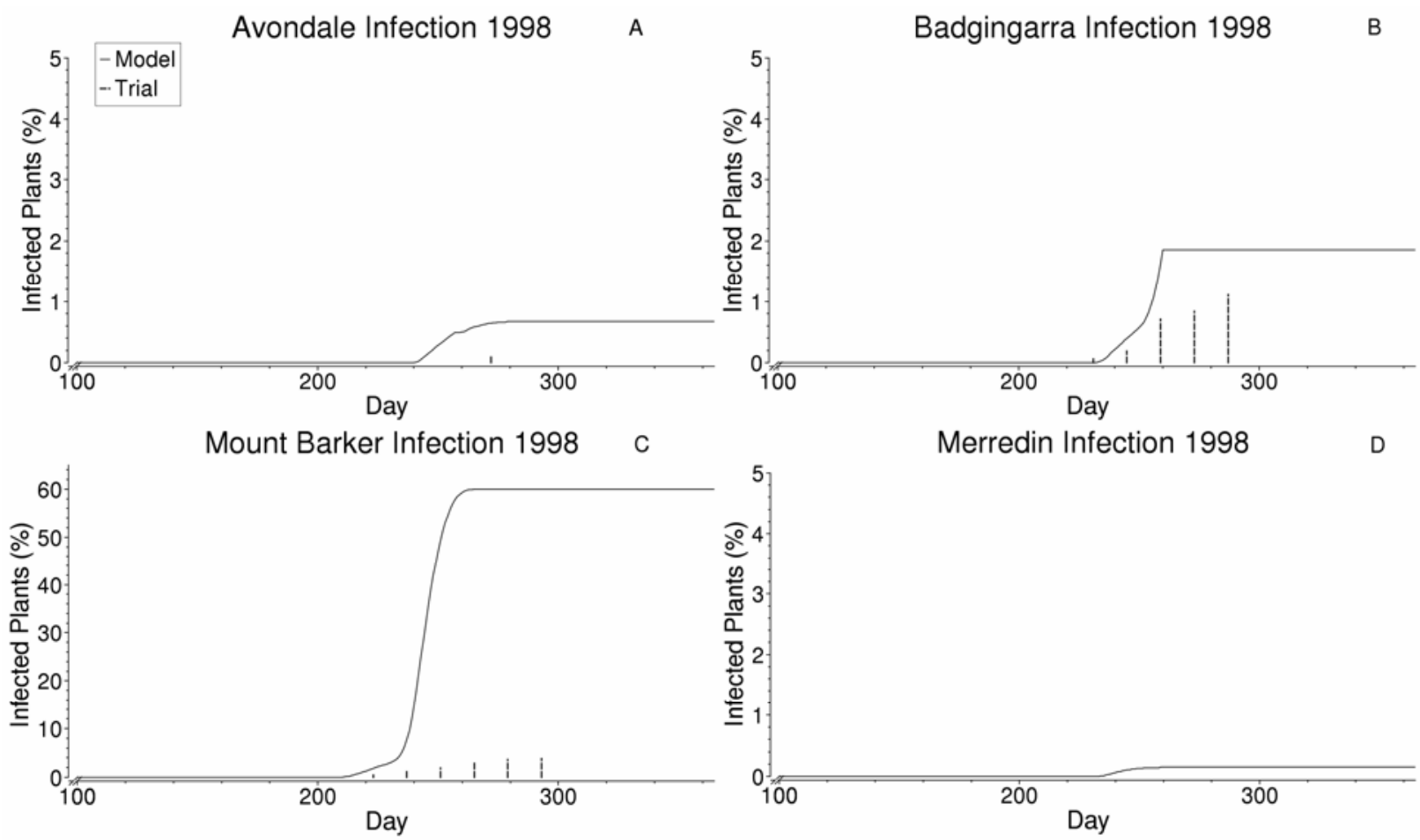

Fig. 6. Observed (trial data) versus predicted (model output) Bean yellow mosaic virus incidence during 1998 at A, Avondale; B, Badgingarra; C, Mount Barker; and $\mathbf{D}$, Merredin. 
lations, with noncolonizing aphids having a greater effect on virus incidence than colonizing aphids. Noncolonizing aphids gave infection ranges of 0.1 to $37 \%$ (1998) and 0.03 to $35 \%$ (1999) while colonizing aphids gave incidences of 1.5 to $3.2 \%$ (1998) and 4.6 to $20 \%$ (1999). BYMV incidence was less sensitive to changes in the number of flights aphids make each day than to their ability to transmit the virus. Noncolonizing aphid flights per day ranged from 0 to 10 , with infection incidences of 0.01 to $2.9 \%$ (1998) to 0.03 to $11.4 \%$ (1999). Colonizing aphid flights per day within the range of 0 to 2 resulted in infection incidences of 1.5 to $1.9 \%$ (1998) and 4.6 to $8.3 \%$ (1999). With latent plant infection period (Llp), BYMV incidence was very responsive over a range of 0 to 30 days, resulting in incidences of 0.02 to $2.6 \%$ (1998) and 0.05 to $19.5 \%$ (1999). BYMV incidence was also very responsive to rate of lupin biomass decline $(\mathrm{Ldec})$, a measure of the temporal effect of BYMV infection on plant biomass, with final incidences of 21.6 to $3.4 \%$ (1998) and 14.1 to $2.3 \%$ (1999).

\section{DISCUSSION}

Our goal was to develop a model to predict vector activity and epidemics of vector-borne viruses spreading from external virus sources to an adjacent crop. To achieve this, a simple hybrid approach was followed using both mechanistic and statistical modeling techniques in model creation and parameter estimation. The model developed was then applied to predict epidemics of an externally sourced, nonpersistently aphid-borne virus with a largely monocyclic pattern of spread within the crop it infects. The pathosystem was BYMV in narrow-leafed lupin, to which the virus spreads from neighboring fields of annually self-regenerating pastures containing infected annual clover plants. Predictions for such pathosystems are important because they facilitate virus management decisions which are otherwise difficult to make due to lack of timely information.

The model of Holt et al. (6) used mechanistic methodology to simulate the epidemiology of Tomato leaf curl virus in tomato crops in order to gain insight into the dynamics of that patho- system. Their approach is useful for exploring qualitative trends between mechanism (inputs and outputs) (e.g., with models aimed at identifying potential control measures) but does not lend itself easily to inclusion of weather variables and so is not suited for use as a forecasting tool (6). The approach of Werker et al. (32) of adapting existing models using knowledge specific to the pathosystem, statistically fitting parameters where possible, and estimating them otherwise represents a modeling philosophy more similar to our own. However, the structure of our model was developed using a more mechanistic approach, modeling pathogen (BYMV), source (clover), vector (aphid), and host (lupin) separately. This approach allowed us to create a more pliable modeling environment that can be adapted for use with other pathogens, sources, vectors, and host crops. By utilizing a mechanistic approach when modeling individual components of the pathosystem rather than employing purely statistical methods, we created a structure that can reproduce behavior that is typical of such systems and is likely to be relatively tolerant of extrapolation. Statistical models could also be used to model the pathosystem but the mechanistic nature of the BYMV model allows flexibility in its use. This is because it has the ability to alter any of the parameters of the submodels in a logical manner (e.g., different vector inoculation efficiencies, reproductive responses to temperature, and so on) because the relationships they are involved in are described mechanistically. The accuracy of the model in any particular set of circumstances comes from calibration using observations in those circumstances rather than derivation from first principals.

Predictions from the BYMV model matched actual experimental data well for seven of the eight aphid population and BYMV incidence scenarios studied. In general, in the years when aphid population densities were predicted well, so were the BYMV disease incidences (thus, the best BYMV incidence predictions in 1999 at Avondale, Badgingarra, and Mount Barker were also the best predictions for aphid population density). It was when our aphid population density predictions were erroneous that our BYMV incidence predictions were also poor. The only
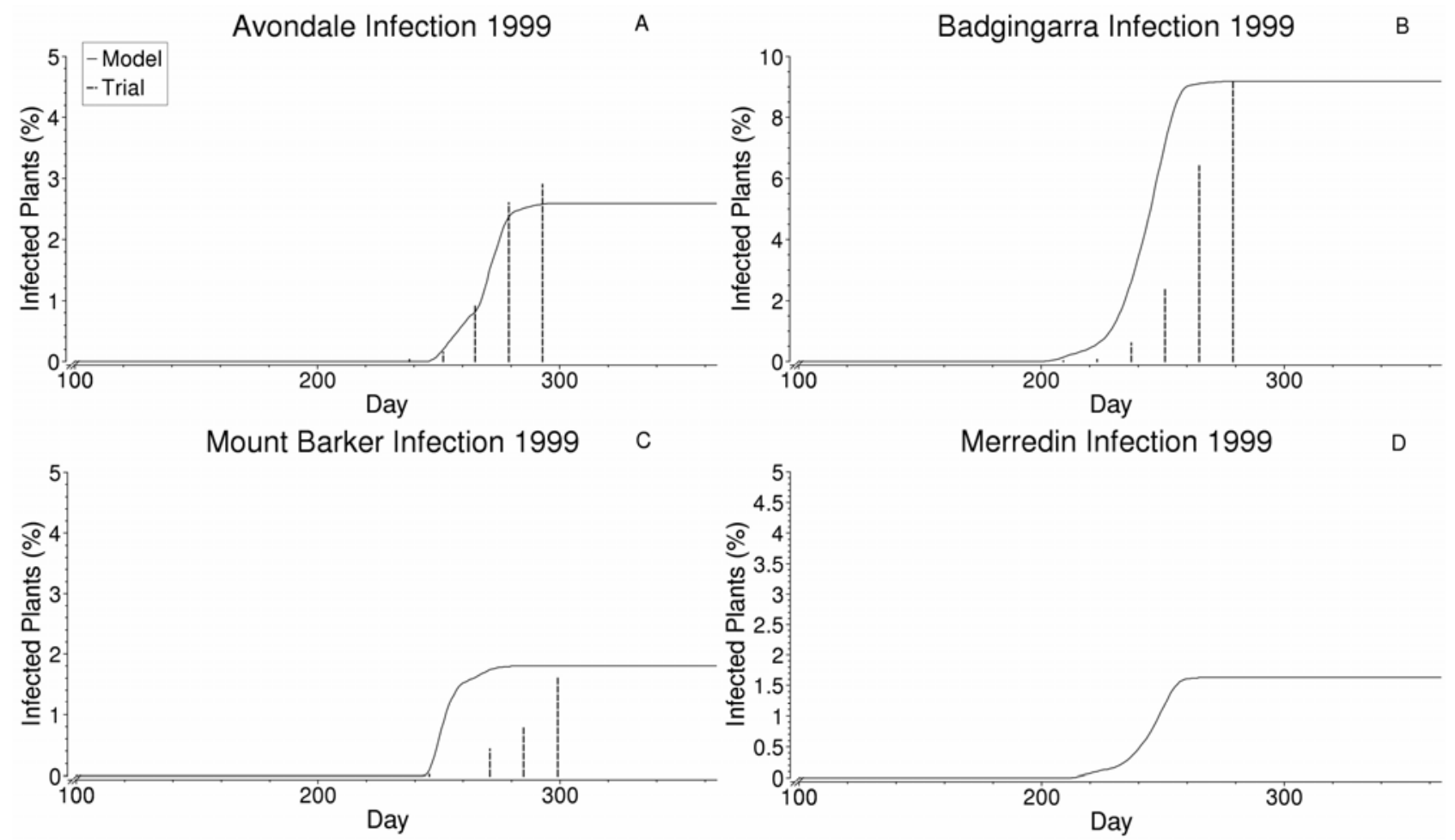

Fig. 7. Observed (trial data) versus predicted (model output) Bean yellow mosaic virus incidence during 1999 at A, Avondale; B, Badgingarra; C, Mount Barker; and $\mathbf{D}$, Merredin. 
TABLE 4. Results of sensitivity analyses to determine the impact of various factors on final Bean yellow mosaic virus (BYMV) incidence in the lupin crop

\begin{tabular}{|c|c|c|}
\hline \multirow[b]{2}{*}{ Factors $^{\mathrm{a}}$} & \multicolumn{2}{|c|}{ Crop BYMV incidence (\%) } \\
\hline & 1998 & 1999 \\
\hline \multicolumn{3}{|l|}{ (i) $\mathrm{De}$} \\
\hline \multicolumn{3}{|l|}{100} \\
\hline 120 & 0 & 0.4 \\
\hline 140 & 0.1 & 2.3 \\
\hline 160 & 1 & 8.8 \\
\hline 180 & 1.9 & 14.7 \\
\hline 200 & 1.4 & 15.7 \\
\hline 220 & 0.5 & 6.7 \\
\hline 240 & 0.1 & 1.5 \\
\hline \multicolumn{3}{|c|}{ (ii) Lpd (plants $/ \mathrm{m}^{2}$ ) } \\
\hline 10 & 2.3 & 15.5 \\
\hline 15 & 1.9 & 14.7 \\
\hline 20 & 1.7 & 12.1 \\
\hline 25 & 1.6 & 10.1 \\
\hline 30 & 1.5 & 8.6 \\
\hline \multicolumn{3}{|l|}{ (iii) Bil } \\
\hline 0 & 0 & 0 \\
\hline 0.1 & 1.9 & 13.3 \\
\hline 0.2 & 3.5 & 20.3 \\
\hline 0.3 & 4.7 & 24 \\
\hline 0.4 & 5.8 & 26.7 \\
\hline 0.5 & 6.6 & 28 \\
\hline \multicolumn{3}{|l|}{ (iv) Aci } \\
\hline 0 & 1.5 & 4.6 \\
\hline 0.2 & 1.9 & 8.3 \\
\hline 0.4 & 2.3 & 11.6 \\
\hline 0.6 & 2.6 & 14.5 \\
\hline 0.8 & 2.9 & 17.3 \\
\hline 1 & 3.2 & 20 \\
\hline \multicolumn{3}{|l|}{ (v) Anie } \\
\hline 0 & 0.1 & 0.03 \\
\hline 0.2 & 4.7 & 18.8 \\
\hline 0.4 & 13.1 & 34.2 \\
\hline 0.6 & 22.5 & 35 \\
\hline 0.8 & 31 & 35 \\
\hline 1 & 37 & 35 \\
\hline \multicolumn{3}{|l|}{ (vi) Fcd } \\
\hline 0 & 1.5 & 4.6 \\
\hline 0.04 & 1.6 & 5.3 \\
\hline 0.08 & 1.7 & 6.1 \\
\hline 0.12 & 1.8 & 6.8 \\
\hline 0.16 & 1.8 & 7.6 \\
\hline 0.2 & 1.9 & 8.3 \\
\hline \multicolumn{3}{|l|}{ (vii) Fnd } \\
\hline 0 & 0.01 & 0.03 \\
\hline 2 & 0.4 & 1 \\
\hline 4 & 0.8 & 2.6 \\
\hline 6 & 1.4 & 5 \\
\hline 8 & 2.1 & 8 \\
\hline 10 & 2.9 & 11.4 \\
\hline \multicolumn{3}{|l|}{ (viii) Llp } \\
\hline 0 & 0.02 & 0.05 \\
\hline 6 & 2.3 & 10.5 \\
\hline 12 & 4.3 & 17.8 \\
\hline 18 & 5 & 19.9 \\
\hline 24 & 3.7 & 19.5 \\
\hline 30 & 2.6 & 19.5 \\
\hline \multicolumn{3}{|c|}{ (ix) Ldec } \\
\hline 0 & 21.6 & 14.1 \\
\hline 0.1 & 11 & 6.8 \\
\hline 0.2 & 6.7 & 4.2 \\
\hline 0.3 & 4.8 & 3.1 \\
\hline 0.4 & 3.9 & 2.6 \\
\hline 0.5 & 3.4 & 2.3 \\
\hline
\end{tabular}

${ }^{a}$ De $=$ crop emergence dates $(\mathrm{i}), \mathrm{Lpd}=$ plant densities (ii), Bil = pasture BYMV incidence (iii), Aci $=$ colonizing (iv) and Anie $=$ noncolonizing (v) aphid inoculation efficiencies, Fcd = number of colonizing (vi) and Fnd = number of noncolonizing (vii) aphid flights per day, Llp = latent infection period (viii), and Ldec = rate of lupin biomass decline due to infection (ix). Two years of meteorological data from the Badgingarra site were used. major disparity between actual and model predicted data was for 1998 at the Mount Barker site. The 1998 growing season started very early compared with 1999 , with extensive rainfall that provided sufficient soil moisture to provide an extra 3-week period of pasture biomass on which aphids could thrive before lupin crops were sown. As such, we would have anticipated a large aphid population to have developed, spreading BYMV throughout the cropping period. Instead, exceptionally low aphid numbers were recorded, the lowest across all sites for both years. The accurate predictions for aphid populations and BYMV incidence in the following year at the same site suggested that an additional factor not accounted for in the model diminished the aphid population in 1998 but was absent in 1999. Possible explanations include frost or extreme wind conditions. Inclusion of these two factors in the aphid population dynamics submodel might help resolve this problem but, at present, no calibration data is available for this. Despite this, the accuracy otherwise achieved is sufficient for its use in guiding BYMV management decisions made by farmers at sowing time, which otherwise must be made without any quantified estimate of potential levels of damage to lupin crops. This can cause significant unnecessary expense in situations where taking control measures is unnecessary.

The results of the sensitivity analysis on parameters taken from the experimental literature (Table 1) showed that final BYMV incidence is most sensitive to changes in noncolonizing aphid inoculation efficiency (Anie) and the rate of BYMV-induced lupin biomass decline (Ldec). The results of the sensitivity analysis of parameters likely to be influenced by farmer management indicated that the model responded plausibly across the likely range of plant densities, emergence dates, and pasture BYMV incidences. BYMV incidence in the pasture source had the greatest effect on final BYMV incidence in the crop, with plant density and emergence dates also contributing. This result provides confidence that the measures recommended for BYMV control are likely to be effective in curtailing BYMV epidemics as part of an IDM strategy targeting (i) rapid canopy closure by adjusting sowing date, row spacing, and seeding rate and (ii) crop hygiene (12). Applying this IDM strategy only when required, based on BYMV risk forecasts, would decrease the financial loss from BYMV infection and encourage increased planting of lupins in regions of high BYMV risk. On this basis, we are employing the model through an automated climate data collection system to forecast incidence of BYMV at 465 localities throughout the West

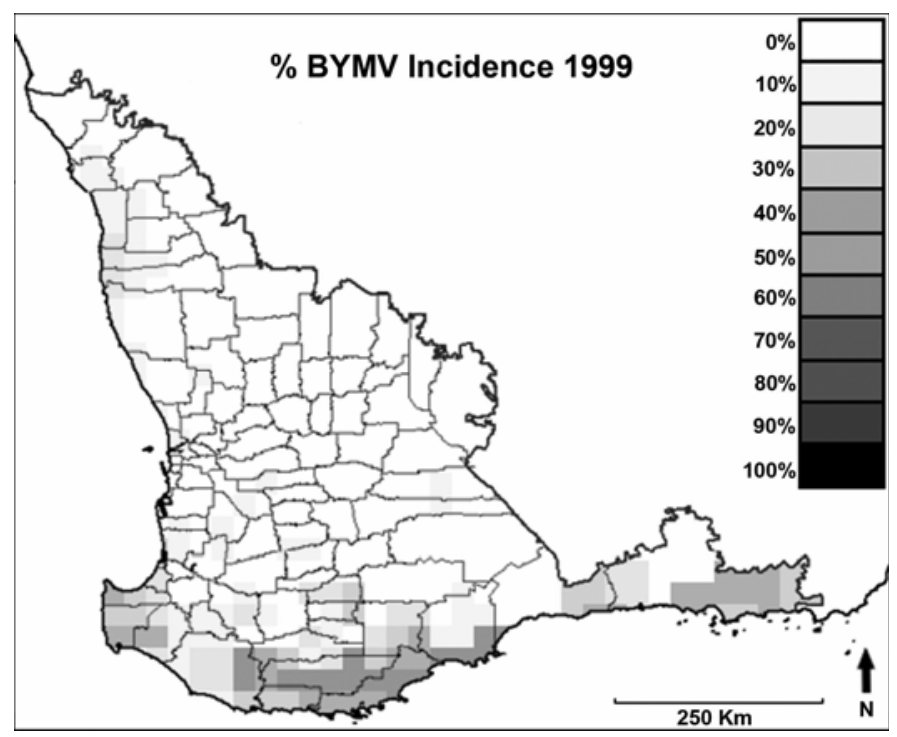

Fig. 8. Bean yellow mosaic virus (BYMV) incidence map for 1999 in different districts in the southwest Australian grainbelt produced using the modeling framework. 
Australian grainbelt. The predicted final BYMV incidence map produced in this way for 1999 is shown in Figure 8. The ability to provide local forecasts of BYMV incidence to lupin farmers in a timely fashion provides them with the opportunity to weigh the economic and environmental cost of applying control measures against the potential loss in crop productivity before deciding whether they need to implement part or all of the full IDM strategy available for BYMV in lupin (12).

We designed a model to predict vector activity and epidemics of vector-borne viruses spreading from external virus sources to an adjacent crop. This generic approach has subsequently facilitated use of the model for other pathosystems, and a variant is currently being used to model the Beet western yellow virus (family, Luteoviridae; genus, Polerovirus)-canola (Brassica napus) pathosystem, which has attributes similar to those described here, except that the virus is persistently aphid-borne not seedborne in the external source plant, and its pattern of within-crop spread is polycyclic (T. Maling, A. J. Diggle, D. J. Thackray, K. H. M. Siddique, and R. A. C. Jones, unpublished data).

\section{ACKNOWLEDGMENTS}

Financial support was provided by the Australian Research Council (ARC) and the Department of Agriculture and Food for Western Australia (DAFWA) through an ARC Linkage Project. The Grains Research and Development Corporation funded previous data collection at the calibration sites. We acknowledge the use of SILO climate data from the Queensland Department of Natural Resources, and thank present and past members of the DAFWA plant virology group and Research Station staff for their contributions to the data used in development and calibration of this model.

\section{LITERATURE CITED}

1. Berlandier, F. A., Thackray, D. J., Jones, R. A. C., Latham, L. J., and Cartwright, L. 1997. Determining the relative roles of different aphid species as vectors of cucumber mosaic and bean yellow mosaic viruses in lupins. Ann. Appl. Biol. 131:297-314.

2. Cheng, Y., and Jones, R. A. C. 1999. Distribution and incidence of necrotic and non-necrotic strains of bean yellow mosaic virus in wild and crop lupins. Aust. J. Agric. Res. 50:589-600.

3. Cheng, Y., and Jones, R. A. C. 2000. Biological properties of necrotic and non-necrotic strains of bean yellow mosaic virus in cool season grain legumes. Ann. Appl. Biol. 136:215-227

4. Cheng, Y., Jones, R. A. C., and Thackray, D. J. 2002. Deploying strain specific hypersensitive resistance to diminish temporal virus spread. Ann. Appl. Biol. 140:69-79.

5. Dixon, A. F. G. 1985. Aphid Ecology, 1st ed. Blackie, Glasgow, UK.

6. Holt, J., Colvin, J., and Muniyappa, V. 1999. Identifying control strategies for tomato leaf curl disease using an epidemiological model. J. Appl. Ecol. 36:625-63.

7. Irwin, M. E., Ruesink, W. G., Isard, S. A., and Kampmeier, G. E. 2000. Mitigating epidemics caused by non-persistently transmitted aphid-borne viruses: The role of the pliant environment. Virus Res. 71:185-211.

8. Jeffrey, S. J., Carter, J. O., Moodie, K. M., and Beswick, A. R. 2001. Using spatial interpolation to construct a comprehensive archive of Australian climate data. Environ. Model. Software 16:309-330.

9. Johnson, W. T., and Lyon, H. H. 1988. Insects that Feed on Trees and Shrubs, 2nd ed. Cornell University Press, Ithaca, NY.

10. Jones, R. A. C. 1993. Effects of cereal borders, admixture with cereals and plant density on the spread of bean yellow mosaic potyvirus into narrow-leafed lupins (Lupinus angustifolius). Ann. Appl. Biol. 122:501-518.
11. Jones, R. A. C. 1994. Effect of mulching with cereal straw and row spacing on spread of bean yellow mosaic potyvirus into narrow-leafed lupins (Lupinus angustifolius). Ann. Appl. Biol. 24:45-58.

12. Jones, R. A. C. 2001. Developing integrated disease management strategies against non-persistently aphid-borne viruses: A model programme. Integr. Pest Manage. Rev. 6:15-46.

13. Jones, R. A. C. 2005. Patterns of spread of two non-persistently aphidborne viruses in lupin stands under four different infection scenarios. Ann. Appl. Biol. 146:337-350.

14. Jones, R. A. C., Coutts, B. A., and Cheng, Y. 2003. Yield limiting potential of necrotic and non-necrotic strains of Bean yellow mosaic virus in narrowleafed lupin (Lupinus angustifolius). Aust. J. Agric. Res. 54:849-859.

15. Jones, R. A. C., and McLean, G. D. 1989. Virus diseases of lupins. Ann. Appl. Biol. 114:609-637.

16. Jones, R. A. C., and Smith, L. J. 2005. Inheritance of hypersensitive resistance to Bean yellow mosaic virus in narrow-leafed lupin (Lupinus angustifolius). Ann. Appl. Biol. 146:539-543.

17. Korie, S., Perry, J. N., Mugglestone, M. A., Clark, S. J., Thomas, C. F. G., and Mohamad Roff, M. N. 2000. Spatiotemporal associations in beetle and virus count data. J. Agric. Environ. Biol. Stat. 5:214-239.

18. Knight, J. D., and Thackray, D. J. 2007. Decision support systems. Pages 677-686 in: Aphids as Crop Pests. H. F. van-Emden and R. Harrington, eds. CAB International, Oxford, UK.

19. Matthews, R. E. F. 1970. Plant Virology, 1st ed. Academic Press, New York.

20. McKirdy, S. J., Coutts, B. A., and Jones, R. A. C. 1994. Occurrence of bean yellow mosaic virus in subterranean clover pastures and perennial native legumes. Aust. J. Agric. Res. 45:183-194.

21. McKirdy, S. J., and Jones, R. A. C. 1995. Bean yellow mosaic potyvirus infection of alternative hosts associated with subterranean clover (Trifolium subterraneum) and narrow-leafed lupins (Lupinus angustifolius): Field screening procedure, relative susceptibility/resistance rankings, seed transmission and persistence between growing seasons. Aust. J. Agric. Res. 46:135-152.

22. McLean, G. D., Garrett, R. G., and Ruesink, W. G., eds. 1986. Plant Virus Epidemics: Monitoring, Modelling and Predicting Outbreaks. Academic Press, Sydney, Australia.

23. O'Keefe, D., Berryman, D. I., Coutts, B. A., and Jones, R. A. C. 2007. Lack of seed coat contamination with Cucumber mosaic virus in lupin permits its reliable large-scale detection in seed. Plant Dis. 91:504-508.

24. Passioura, J. B. 1996. Simulation models: Science; snake oil, education, or engineering? Agron. J. 88:690-694.

25. Ruesink, W. G., and Irwin, M. E. 1986. Soybean mosaic virus epidemiology: A model and some implications. Pages 295-315 in: Plant Virus Epidemics: Monitoring, Modelling and Predicting Outbreaks. Academic Press, Sydney, Australia.

26. Silsbury, J. H., and Hancock, T. W. 1990. Growth responses of cultivars of subterranean clover to temperature, plant density and nitrate supply. Aust. J. Agric. Res. 41:101-114.

27. Silsbury, J. H., Zuill, D., and Brown, P. H. 1984. Effects of temperature on germination, emergence and early seedling growth of swards of Mt Barker subterranean clover plants grown with and without nitrate. Aust. J. Agric. Res. 35:539-549.

28. Thackray, D. J., Diggle, A. J., Berlandier, F. A., and Jones, R. A. C. 2004. Forecasting aphid outbreaks and epidemics of Cucumber mosaic virus in lupin crops in a Mediterranean-type environment. Virus Res. 100:67-82.

29. Thackray, D. J., and Jones, R. A. C. 1999. Forecasting aphid and virus risk in lupins. Pages 24-26 in: Lupin Updates 1999. Agribusiness Crop Updates 1999, Agriculture Western Australia, South Perth, Western Australia.

30. Thackray, D. J., and Jones, R. A. C. 2000. Forecasting aphid and virus risk in lupins. Pages 19-21 in: Lupin Updates 2000. Agribusiness Crop Updates 2000. Agriculture Western Australia, South Perth, Western Australia.

31. Thackray, D. J., Smith, L. J. Cheng, Y., Perry, J. N., and Jones, R. A. C. 2002. Effect of strain-specific hypersensitive resistance on spatial patterns of virus spread. Ann. Appl. Biol. 141:45-59.

32. Werker, A. R., Dewar, A. M., and Harrington, R. 1998. Modeling the incidence of virus yellows in sugar beet in the UK in relation to numbers of migrating Myzus persicae. J. Appl. Ecol. 35:811-818. 